\title{
Metabolic syndrome and diabetes for the urologist
}

\author{
Neil E. Fleshner, MD, MPH, FRCSC,; Bimal Bhindi, $M D^{t}$
}

*Professor of Surgery and Martin Barkin Chair of Urology, University of Toronto, Head, Division of Urology, University Health Network, Love Chair in Prostate Cancer Prevention, Princess Margaret Hospital, Toronto, ON; 'Resident in Urology, University of Toronto, Toronto, ON

Cite as: Can Urol Assoc J 2014;8(7-8):S159-61. http://dx.doi.org/10.5489/cuaj.2314

Published online August 11, 2014.

\section{Abstract}

Type 2 diabetes has a number of know urological consequences. Epidemiologic and clinical data suggest a link between metabolic syndrome and prostatic diseases, such as benign prostatic hyperplasia $(\mathrm{BPH})$ and prostate cancer. Recent studies have identified metformin as a viable treatment for patients with type 2 diabetes and prostate cancer.

M etabolic syndrome comprises a constellation of metabolic abnormalities that are associated with an increased risk of cardiovascular (CV) disease, type 2 diabetes, CV-specific mortality, and all-cause mortality. ${ }^{1,2}$ The definition of metabolic syndrome varies according to different sources, but generally comprises a series of factors involving insulin resistance, increased body weight, increased lipid levels, high blood pressure and impaired glucose levels (Table 1)..$^{3-7}$

The prevalence of metabolic syndrome in Canada is estimated at $19 \% .{ }^{8}$ Dietary excess and a sedentary lifestyle are thought to contribute to the development of metabolic syndrome in genetically susceptible individuals.

The development of diabetes follows a series of stages, beginning with insulin resistance in peripheral tissues, resulting in glucose intolerance. At this stage, a postprandial rise in glucose may be the only sign of metabolic disturbance. With increased insulin resistance, the patient reaches a state of hyperinsulinemia combined with hyperglycemia - a stage that is often referred to as "pre-diabetes," during which the cells become increasingly starved for energy. During the hyperinsulinemic phase of type 2 diabetes, glucose levels rise above safe levels. Finally, during the burnout phase, beta-cells are no longer able to produce insulin. Insulin resistance occurs years before the onset of type 2 diabetes, due to genetic factors as well as environmental factors, such as sedentary lifestyle, pregnancy, nutrient intake (quantity and quality), puberty and aging. The net result is adiposity, impaired B-cell function, and impaired insulin action.
Type 2 diabetes can result in a number of urological consequences. Renal consequences may include kidney stones, pyelonephritis/inflammation or chronic renal failure. In the bladder, urinary tract infections or cystopathy/retention may develop. Infertility, andropause and erectile dysfunction are also known urological consequences of type 2 diabetes. ${ }^{9}$

Recent epidemiologic and clinical data suggest a link between metabolic syndrome and prostatic diseases, such as benign prostatic hyperplasia (BPH) and prostate cancer. ${ }^{10}$ Many of the hormones, growth factors, cytokines and other mediators associated with obesity and the metabolic syndrome enable crosstalk between macrophages, adipocytes, endothelial cells and epithelial cells, which is implicated in carcinogenesis (including growth signaling, inflammation, and vascular alterations). ${ }^{11}$ A recent study at the University of Toronto found that men with 3 or more components of the metabolic syndrome had a 38\% higher odds of being diagnosed with prostate cancer than men with no risk factors. ${ }^{12}$ These men also had a $52 \%$ higher odds of being diagnosed with clinically significant prostate cancer and a $43 \%$ higher odds of being diagnosed with high-grade prostate cancer (Gleason 7 or higher). These findings suggest a biologic gradient with increasing number of metabolic risk factors. As well, androgen deprivation therapy, used in the treatment of prostate cancer, can induce alterations similar to those of metabolic syndrome, including increased obesity, decreased insulin sensitivity and altered lipid profiles. ${ }^{13}$

Recent data suggest that men with type 2 diabetes and prostate cancer have improved survival when treated with the biguanide oral hypoglycemic agent metformin. Among men with diabetes in a population-based, retrospective cohort of 3837 patients, cumulative duration of treatment with the antidiabetic metformin following a diagnosis of prostate cancer was associated with declines in both all-cause mortality and prostate cancer-specific mortality. ${ }^{14}$ However, despite these findings of improved survival in men with an existing diagnosis of prostate cancer, metformin does not seem to prevent the development of prostate cancer in men with type 2 diabetes. A retrospective review of 5306 diabetic men with prostate cancer and 26530 matched controls 
Fleshner and Bhindi

\begin{tabular}{|c|c|c|c|c|c|}
\hline Clinical measure & WHO $(1998)^{3}$ & ATP III $(2001)^{4}$ & IDF $(2005)^{5}$ & AHA/NHLBI $(2005)^{6}$ & $\begin{array}{l}\text { IDF \& AHA/NHLBI } \\
\text { Joint Interim (2009)7 }\end{array}$ \\
\hline Insulin resistance & $\begin{array}{c}\text { Mandatory } \\
\text { IGT, IFG, T2DM, } \\
\text { or lowered insulin } \\
\text { sensitivity* plus any } 2 \\
\text { of the following }\end{array}$ & $\begin{array}{l}\text { None, but any } 3 \text { of the } \\
\text { following } 5 \text { features }\end{array}$ & None & $\begin{array}{c}\text { None, but any } 3 \\
\text { of the following } 5 \\
\text { features }\end{array}$ & \\
\hline Body weight & $\begin{array}{l}\text { Men: waist-to-hip } \\
\text { ratio >0.90; women: } \\
\text { waist-to-hip ratio } \\
>0.85 \text { and/or BMl } \\
>30 \mathrm{~kg} / \mathrm{m}^{2}\end{array}$ & $\begin{array}{l}W C \geq 102 \mathrm{~cm} \text { in men } \\
\text { or } \geq 88 \mathrm{~cm} \text { in woment }\end{array}$ & $\begin{array}{c}\text { Mandatory } \\
\text { Increased WC } \\
\text { (population specific) } \\
\text { plus any } 2 \text { of the } \\
\text { following }\end{array}$ & $\begin{array}{l}W C \geq 102 \mathrm{~cm} \text { in men } \\
\text { or } \geq 88 \mathrm{~cm} \text { in woment }\end{array}$ & $\begin{array}{c}\text { Ethnicity/pop-specific } \\
\text { WC }\end{array}$ \\
\hline $\begin{array}{l}\text { Lipid } \\
\text {-High TG } \\
\text {-Low HDL }\end{array}$ & $\begin{array}{c}\mathrm{TG} \geq 150 \mathrm{mg} / \mathrm{dL} \text { and } / \mathrm{or} \\
\mathrm{HDL}-\mathrm{C}<35 \mathrm{mg} / \mathrm{dL} \text { in } \\
\text { men or }<39 \mathrm{mg} / \mathrm{dL} \text { in } \\
\text { women }\end{array}$ & $\begin{array}{c}\mathrm{TG} \geq 150 \mathrm{mg} / \mathrm{dL} \\
\mathrm{HDL}-\mathrm{C}<40 \mathrm{mg} / \mathrm{dL} \text { in } \\
\text { men or }<50 \mathrm{mg} / \mathrm{dL} \text { in } \\
\text { women }\end{array}$ & $\begin{array}{c}\mathrm{TG} \geq 150 \mathrm{mg} / \\
\mathrm{dL} \text { or on } \mathrm{TG} \mathrm{Rx} \\
\mathrm{HDL}-\mathrm{C}<40 \mathrm{mg} / \mathrm{dL} \text { in } \\
\text { men or }<50 \mathrm{mg} / \mathrm{dL} \text { in } \\
\text { women or on HDL-C } \\
\mathrm{Rx}\end{array}$ & $\begin{array}{c}\mathrm{TG} \geq 150 \mathrm{mg} / \mathrm{dL} \\
\mathrm{HDL}-\mathrm{C}<40 \mathrm{mg} / \mathrm{dL} \text { in } \\
\text { men or }<50 \mathrm{mg} / \mathrm{dL} \text { in } \\
\text { women } \\
\text { Or use of specific } \\
\text { drug for this (nicotinic } \\
\text { acid or fibrate) }\end{array}$ & $\begin{array}{c}\mathrm{TG} \geq 150 \mathrm{mg} / \mathrm{dL} \\
\mathrm{HDL}-\mathrm{C}<40 \mathrm{mg} / \mathrm{dL} \text { in } \\
\text { men or }<50 \mathrm{mg} / \mathrm{dL} \text { in } \\
\text { women } \\
\text { Or use of specific } \\
\text { drug for this (nicotinic } \\
\text { acid or fibrate) }\end{array}$ \\
\hline Blood pressure & $\geq 140 / 90 \mathrm{mmHg}$ & $\geq 130 / 85 \mathrm{mmHg}$ & $\begin{array}{c}\geq 130 \mathrm{mmHg} \text { systolic } \\
\text { or } \geq 85 \mathrm{mmHg} \\
\text { diastolic or on } \\
\text { hypertension } \\
\text { medication }\end{array}$ & $\begin{array}{l}\geq 130 / 85 \mathrm{mmHg} \text { or } \\
\text { medical treatment for } \\
\text { hypertension }\end{array}$ & $\begin{array}{l}\geq 130 / 85 \mathrm{mmHg} \text { or } \\
\text { medical treatment for } \\
\text { hypertension }\end{array}$ \\
\hline Glucose & $\begin{array}{c}\text { Mandatory } \\
\text { IGT, IFG, or T2DM }\end{array}$ & $\begin{array}{c}>110 \mathrm{mg} / \mathrm{dL} \text { (includes } \\
\text { diabetes) } \ddagger\end{array}$ & $\begin{array}{c}\geq 100 \mathrm{mg} / \mathrm{dL} \text { (includes } \\
\text { diabetes) }\end{array}$ & $\begin{array}{c}>100 \mathrm{mg} / \mathrm{dL} \text { (includes } \\
\text { diabetes) } \ddagger\end{array}$ & $\begin{array}{c}\geq 100 \mathrm{mg} / \mathrm{dL} \text { (includes } \\
\text { diabetes) }\end{array}$ \\
\hline
\end{tabular}

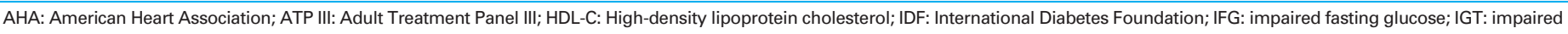

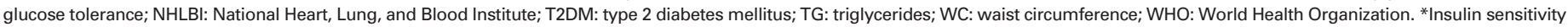

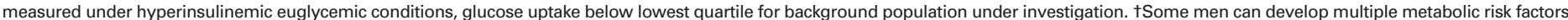

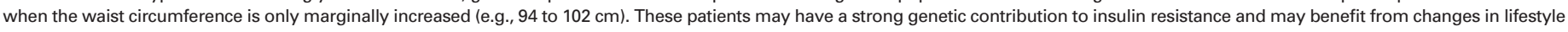

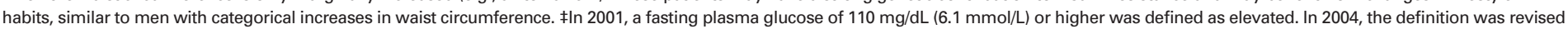
to $100 \mathrm{mg} / \mathrm{dL}(5.6 \mathrm{mmol} / \mathrm{L})$ or higher, in accordance with the American Diabetes Association's updated definition of IFG. ${ }^{16-18}$

found no association between cumulative metformin use and the risk of developing prostate cancer. ${ }^{15}$

The Metformin Active Surveillance Trial (MAST) study is currently exploring whether metformin will delay progression of prostate cancer. A total of 404 men with low-risk prostate cancer undergoing active surveillance have been randomly assigned to receive metformin $(850 \mathrm{mg}$ bid) or placebo for 3 years. The primary end point is time to progression, defined as the need for primary prostate cancer therapy (e.g., prostatectomy, radiation or hormone therapy) as a result of pathological progression.

\section{Conclusion}

Type 2 diabetes and metabolic syndrome are important factors in many aspects of prostate cancer. Recent evidence has shown that metformin may be a viable treatment for patients with type 2 diabetes and prostate cancer. Ongoing studies are exploring the possibility that metformin may also play a role in the progression of early stage prostate cancer.

Regardless of a diagnosis of prostate cancer, the urologist should be aware of the potential effects of diabetes and metabolic syndrome on the prostate and other urological systems.
Competing interests: Dr. Bhindi does not declare competing financial or personal interests. Dr. Fleshner is a member of the Advisory Board for Amgen, Janssen, Astellas and Eli Lilly. He has received honoraria from Amgen, Janssen, Astellas and Eli Lilly. He is and has participated in clinical trials for Amgen, Janssen, Medivation, Ontario Institute for Cancer Research (OICR), and Prostate Cancer Canada.

\section{References}

1. Meigs JB, Wilson PW, Fox CS, et al. Body mass index, metabolic syndrome, and risk of type 2 diabetes or cardiovascular disease. J Clin Endocrinol Metab 2006;91:2906-12. http://dx.doi.org/10.1210/ic.2006-0594

2. Mottillo S, Filion KB, Genest J, et al. The metabolic syndrome and cardiovascular risk: A systematic review and meta-analysis. J Am Coll Cardiol 2010;56:1113-32. http://dx.doi.org/10.1016/i.jacc.2010.05.034

3. Alberti KG, Zimmet PZ. Definition, diagnosis and classification of diabetes mellitus and its complications. Part 1: Diagnosis and classification of diabetes mellitus provisional report of a WHO consultation. Diabet Med 1998;15:539-53. http://dx.doi.org/10.1002/(SICI) 1096-9136(199807) 15:7<539::AIDDIA668>3.0. C0;2-S

4. Expert Panel on Detection, Evaluation, and Treatment of High Blood Cholesterol in Adults. Executive Summary of The Third Report of The National Cholesterol Education Program (NCEP) Expert Panel on Detection, Evaluation, And Treatment of High Blood Cholesterol In Adults (Adult Treatment Panel III). JAMA 2001;285:2486-97. http://dx.doi.org/10.1001/jama.285.19.2486

5. Alberti KG, Zimmet P, Shaw J; IDF Epidemiology Task Force Consensus Group. The metabolic syndrome: A new worldwide definition. Lancet 2005;366:1059-62. http://dx.doi.org/10.1016/S0140-6736(05)67402-8

6. Grundy SM, Cleeman II, Daniels SR, et al. Diagnosis and management of the metabolic syndrome: An American Heart Association/National Heart, Lung, and Blood Institute Scientific Statement. Circulation 2005; 112:273552. hitrp://dx.doi.org/10.1161/CIRCULATIONAHA.105.169404 
Metabolic syndrome and diabetes

7. Alberti KG, Eckel RH, Grundy SM, et al; International Diabetes Federation Task Force on Epidemiology and Prevention; National Heart, Lung, Blood Institute; American Heart Association; World Heart Federation; International Atherosclerosis Society; International Association for the Study of Obesity. Harmonizing the Metabolic Syndrome. A Joint Interim Statement of the International Diabetes Federation Task Force on Epidemiology and Prevention; National Heart, Lung, and Blood Institute; American Heart Association; World Heart Federation; International Atherosclerosis Society; and International Association for the Study of Obesity. Circulation 2009;120:1640-5. http://dx.doi.org/10.1161/CIRCULATIONAHA.109.192644

8. Ruderman NB, Carling D, Prentki M, et al. AMPK, insulin resistance, and the metabolic syndrome. J Clin Invest 2013;123:2764-72. http://dx.doi.org/10.1172/JCl67227

9. Fode M, Krogh-Jespersen S, Brackett NL, et al. Male sexual dysfunction and infertility associated with neurological disorders. Asian J Androl 2012;14:61-8. http://dx.doi.org/10.1038/aja.2011.70

10. De Nunzio C, Aronson W, Freedland SJ, et al. The correlation between metabolic syndrome and prostatic diseases. Eur Urol 2012;61:560-70. htrp://dx.doi.org/10.1016/i.eururo.2011.11.013

11. Hursting SD, Hursting MJ. Growth signals, inflammation, and vascular perturbations: Mechanistic links between obesity, metabolic syndrome, and cancer. Arterioscler Thromb Vasc Biol 2012;32:1766-70. http://dx.doi. org/10.1161/ATVBAHA.111.241927

12. Bhindi B, Margel D, Hamilton R, et al. Impact of metabolic syndrome on the risk of prostate caner and high grade disase among men presenting for prostate biopsy. Canadian Urological Association Annual Meeting; Niagara Fall, ON; June 24, 2013. Abstr MP-01-16.
13. Saylor PJ, Smith MR. Metabolic complications of androgen deprivation therapy for prostate cancer. J Urol 2013;189:S34-42. http://dx.doi.org/10.1016/i.juro.2012.11.017

14. Margel D, Urbach DR, Lipscombe LL, et al. Metformin use and all-cause and prostate cancer-specific mortality among men with diabetes. J Clin Oncol 2013;31:3069-75. http://dx.doi.org/10.1200/JC0.2012.46.7043

15. Margel D, Urbach D, Lipscombe LL, et al. Association between metformin use and risk of prostate cancer and its grade. J Natl Cancer Inst 2013;105:1123-31. http://dx.doi.org/10.1093/inci/dit170

16. Mclaughlin $T$, Allison $G$, Abbasi $F$, et al. Prevalence of insulin resistance and associated cardiovascular disease risk factors among normal weight, overweight, and obese individuals. Metabolism 2004;53:495-9. http:// dx.doi.org/10.1016/i.metabol.2003.10.032

17. Hu FB, Meigs JB, Li TY, et al. Inflammatory markers and risk of developing type 2 diabetes in women. Diabetes 2004;53:693-700. http://dx.doi.org/10.2337/diabetes.53.3.693

18. Grundy SM, Hansen B, Smith SC Jr, et al.; American Heart Association; National Heart, Lung, and Blood Institute; American Diabetes Association. Clinical management of metabolic syndrome: report of the American Heart Association/National Heart, Lung, and Blood Institute/American Diabetes Association conference on scientific issues related to management. Circulation 2004;109:551-6. http://dx.doi.org/10.1161/01. CIR.0000112379.88385.67

Correspondence: Dr. Neil Fleshner, 610 University Ave., Suite 3-130, Toronto ON M5G 2M9; neil.fleshner@uhn.on.ca 